\title{
ENHANCED POWER SOURCES COMPATIBLE WITH EXTENDED THERMAL ENVIRONMENT
}

\author{
Yvan Reynier ${ }^{(1)}$, Florence Fusalba ${ }^{(1)}$,Julien Labbé( ${ }^{(2)}$, Valery Gineste ${ }^{(2)}$, Brandon Bürgler ${ }^{(3)}$ \\ (1) CEA-LITEN (French Atomic and Renewable Energy Commission), 17 rue des Martyrs, 38054 Grenoble \\ (France)yvan.reynier@cea.fr \\ (2) Airbus Defence and Space, 51-61, route de Verneuil, 78130 Les Mureaux, France \\ valery.gineste@astrium.eads.net \\ (3) European Space Agency, ESTEC, Keplerlaan 1, Postbox 299, 2200 AG Noordwijk, The Netherlands \\ brandon.buergler@esa.int
}

\begin{abstract}
Today the race to lower the cost to orbit is stronger than ever, with the arrival of new competitors like Space-X. A way to lighten European next generation launchers (Ariane 6) is to use novel primary and secondary batteries for powering avionics, pyro systems, guidance and control electronics, as well as communication systems.

Such application requires unrestricted operations at low temperature $\left(-20^{\circ} \mathrm{C}\right)$ and safety behaviour at high temperature $\left(70^{\circ} \mathrm{C}\right)$, in addition to a low self-discharge rate because most of the life time of the power source goes by under storage prior to launch. Several battery technologies could be used for this application. While the major challenge for Lithium primary cells is the power capability, regarding secondary Li-ion batteries it may be self-discharge. Both technologies will need a good low temperature power rate capability.

CEA developed $18650 \mathrm{Li}$-ion cells and AA Li-CF ${ }_{x}$ cells in order to tackle those particular challenges.
\end{abstract}

\section{INTRODUCTION}

Electrical power generation has not been a big issue for the Ariane Launch Vehicle family since the beginning, because the range of power needed to supply electrical systems was very low, mainly since Thrust Vector Control (TVC) systems was essentially hydraulic and range of energy needed was also very low (mission duration, essentially Geostationary Transfer Orbits (GTO) are very short).

Consequently, power source technologies remained unchanged for a long time: Ag-Zn batteries for avionics and $\mathrm{Ni}-\mathrm{Cd}$ batteries for pyros.

This is going to be strongly modified in the frame of the next European launcher Ariane 6 that will be "more electrical" than current European Launch Vehicles, and could be an "all electrical vehicle".

From the launcher system point of view, it seems appropriate to focus on the functional and the High Power TVC need as they represent critical functions with respect to on board equipment weight and impact on launcher performance.

The pyrotechnics and safeguard functions could be assessed later, in light of the results obtained during the study. More precisely, the electrochemical technologies that have been chosen to be prototyped and tested could be assessed for these two applications in a second loop that could take place after the first test campaign.

Rechargeable batteries are especially needed for the TVC function where high specific energy and specific power are requested with high currents charge capability.

For functional power supply (FPS), primary batteries are preferred for highest energy density, even if high energy secondary batteries may be appropriate. Cycle life requirements of these missions are minimal.

CEA strategy to meet the high power supply (HPS) TVC target was to select a «power sized » chemistry to embed more useful capacity or avoid battery oversizing while better operating at low temperature range $\left(-20^{\circ} \mathrm{C}\right)$ in a power mode. Two technologies were selected and optimized in 18650 format: NMC-LTO with high power sizing ( 20C rate) and NMC-Si for medium power (5C) high energy sizing. Silicon offers very high specific capacity at the expense of low cyclability due to volume expansion during lithium insertion [1]. However since launcher is not recovered a few cycles is enough to validate performance prior to launch and fulfil the mission.

For the FPS application, $\mathrm{CF}_{\mathrm{x}}$ primary lithium battery was selected for its very high energy density $(>275 \mathrm{Wh} / \mathrm{kg}$ possible at cell level). Blending with other materials $\left(\mathrm{MnO}_{2}, \mathrm{~V}_{2} \mathrm{O}_{5}\right)$ was studied but did not show any improvement regarding low temperature performance. After electrode and design optimizing to maximize power capability, prototypes developed in AA 14500 format were also tested.

\section{EXPERIMENTAL}

Pack sizing calculation made for the TVC application lead to a cell capacity best matched by the 18650 format. This cylindrical cell is a Li-ion standard first produced by Sony Corporation in the 1990's, who was the first producer of Li-ion cells. It was later adopted by all the industry in consumer market electronics, and is even used today for automotive applications (Tesla 
model S) and low earth orbit satellites.

The format is defined as follows (Figure 1):

- Height : $65 \mathrm{~mm}$

- Diameter : $18 \mathrm{~mm}$

- Hard casing (Steel) with crimped positive cap
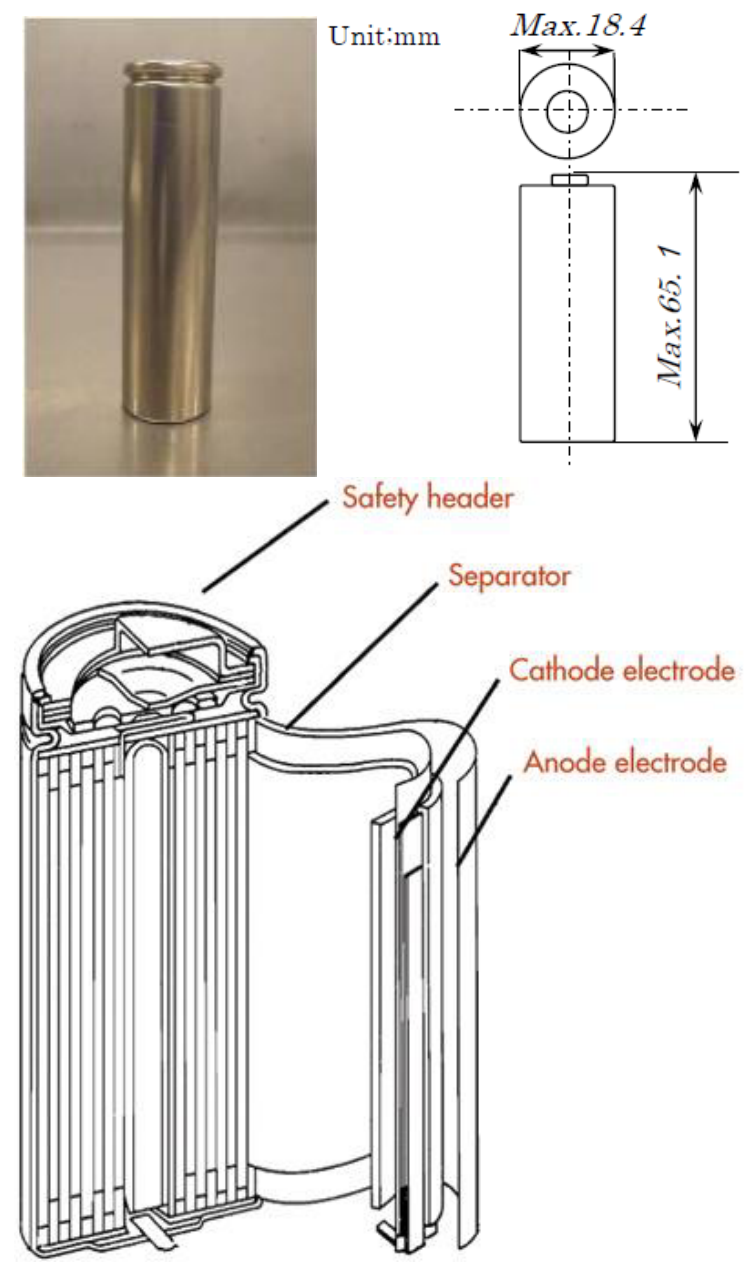

Figure 1. Picture of CEA 18650 cell and internal design

The casing is made of steel and ordered from Hohsen Corporation. The cap includes a safety vent. No PTC device was included to minimize internal resistance.

- For the NMC/Si secondary system, an electrode length of $760 \mathrm{~mm}$ was calculated, resulting in 2.4 Ah capacity at $3.4 \mathrm{~V}$ average voltage

- Due to the thinner electrodes, the NMC/LTO system positive is $1080 \mathrm{~mm}$ long, with a capacity of $0.6 \mathrm{Ah}$ at $2.3 \mathrm{~V}$ average voltage.

Primary cells were defined to be manufactured using a stainless steel AA 14500 laser welded cylindrical format (Figure 2).

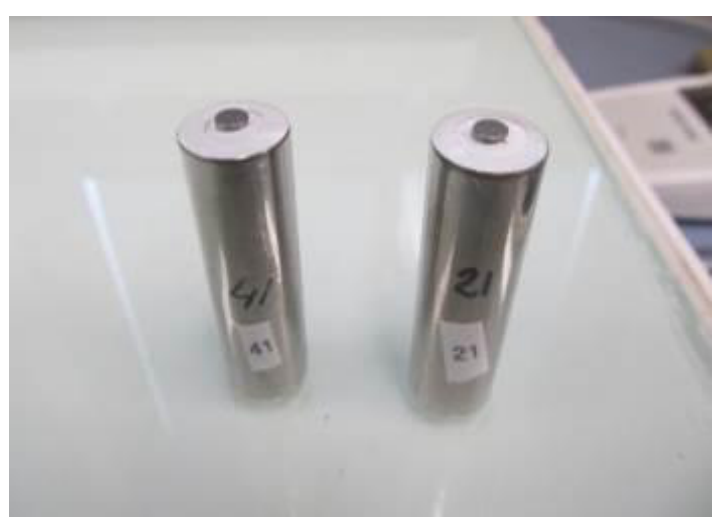

Figure 2. CEA AA 14500 cell format

The format is defined as follows:

- Height : $50 \mathrm{~mm}$

- Diameter : $14 \mathrm{~mm}$

- Glass to metal seals, laser welded cap

Thanks to the glass to metal seal and all laser welded design, this cell can withstand the high vacuum levels of space.

For this primary system, an electrode length of $656 \mathrm{~mm}$ was calculated, resulting in $1.9 \mathrm{Ah}$ capacity at $2.4 \mathrm{~V}$ average voltage.

Mission profiles and test plans were designed by Airbus DS and prototype cells tested at their facilities in representative conditions.

\section{RESULTS}

Performance results in standard conditions as well as in representative mission profile for both technologies were collected and compared.

\subsection{Li-ion secondary cells}

Cells were assembled in 18650 format and their performance compared.

Thanks to silicon's very high specific capacity $(>1000 \mathrm{mAh} / \mathrm{g})$ compared to graphite $(350 \mathrm{mAh} / \mathrm{g})$, high energy electrodes can be designed with relatively low thickness. It enable fast $\mathrm{Li}$ ion diffusion and high resulting power. Electrolyte was also specifically tuned for low temperature and silicon (ethylene carbonate free composition).

18650 cells using nickel manganese cobalt oxide cathode and silicon anode (NMC/Si) showed a relatively high energy density of $200 \mathrm{Wh} / \mathrm{kg}$ for powersized cell and very low impedance of $16 \mathrm{~m} \Omega$ at $1 \mathrm{kHz}$. The rate capability curve at room temperature is shown in Fig. 3. From this curves the continuous power can be extracted and is presented in Tab 1. The cells keep steady performance in the $\mathrm{C} / 3$ to $5 \mathrm{C}$ current range. 


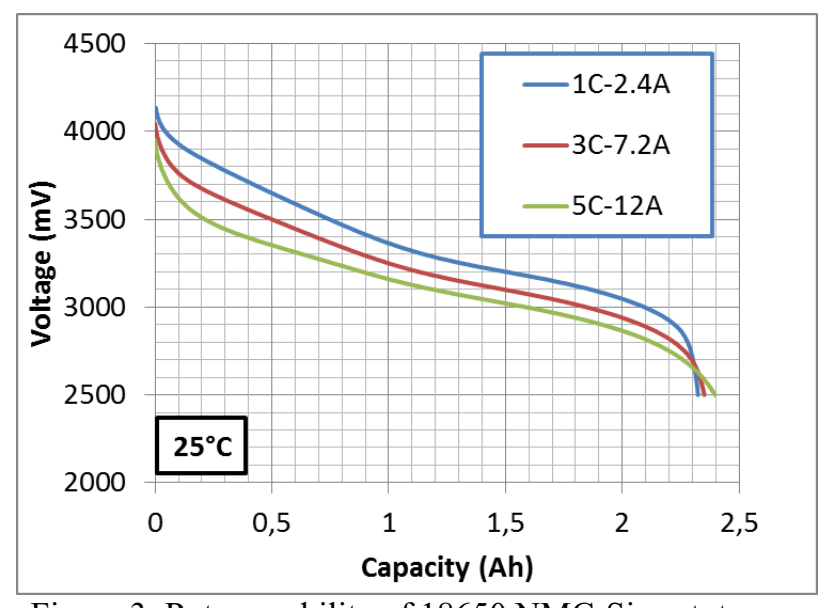

Figure 3. Rate capability of 18650 NMC-Si prototypes

Table 1 . Continuous power capability at $25^{\circ} \mathrm{C}$ for NMCSi 18650 cells

\begin{tabular}{|c|c|c|c|}
\hline C-rate & $\mathbf{W h} / \mathbf{k g}$ & $\mathbf{W} / \mathbf{k g}$ (90\% SoC) & $\mathbf{W} / \mathbf{k g}$ (50\%SoC) \\
\hline 0,33 & 198 & 74 & 65 \\
\hline 1 & 186 & 218 & 192 \\
\hline 3 & 181 & 625 & 555 \\
\hline 5 & 178 & 992 & 893 \\
\hline
\end{tabular}

Lithium titanium oxide (LTO) is known for its high power capability and fast charge tolerance.

NMC/LTO cells were developed and designed for very high power. They delivered $65 \%$ capacity at 20C (Fig. 4). However, low temperature performance was not good enough to meet the target, probably due to further LTO material conductivity improvement need (for example by tuning particle size).

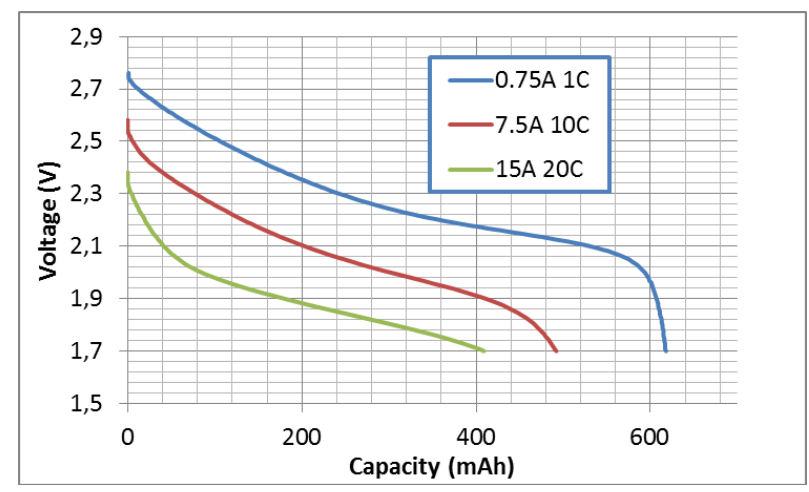

Figure 4. Rate capability of 18650 NMC-LTO cells

After a first selection of the most promising chemistry, namely (NMC/Si), it was further tested at low and high temperature by Airbus defence and space (DS).

NMC/Si 18650 cells passed all the TVC launchers mission profiles designed by Airbus DS to validate the technologies, ranging from -20 to $+70^{\circ} \mathrm{C}$, as summarized in Tab 2. (Example in Fig. 5). Vibration testing was also successful: no artefact on voltage was noted during vibration test and cells were fully operational after vibration.

Table 2: 18650 cells test plan summary

\begin{tabular}{|c|c|}
\hline \multicolumn{2}{|l|}{$18650:$ NMC - Si } \\
\hline Sequence High Power Supply (HPS) & Status \\
\hline Mission cycling: $\mathrm{HPS}$ boosts at $-20^{\circ} \mathrm{C}$ & Passed $\sqrt{ }$ \\
\hline Mission cycling: HPS boosts at $-10^{\circ} \mathrm{C}$ & Passed $\sqrt{ }$ \\
\hline Mission cycling: HPS boosts at $0^{\circ} \mathrm{C}$ & Passed $\sqrt{ }$ \\
\hline Mission cycling: HPS boosts at $20^{\circ} \mathrm{C}$ & Passed $\sqrt{ }$ \\
\hline Mission cycling: HPS boosts at $70^{\circ} \mathrm{C}$ & Passed $\sqrt{ }$ \\
\hline Mission cycling: FPS GTO/GTO+ at $-20^{\circ} \mathrm{C}$ & Passed $\sqrt{ }$ \\
\hline Calendar test: $\quad 6$ months at $20^{\circ} \mathrm{C}$ & Passed $\sqrt{ }$ \\
\hline Mechanical tests : & \\
\hline $\begin{array}{l}\text { Critical frequency search test \#1 } \\
\text { Vibration : Sine + Random } \\
\text { Critical frequency search test \#2 }\end{array}$ & Passed $\sqrt{ }$ \\
\hline
\end{tabular}

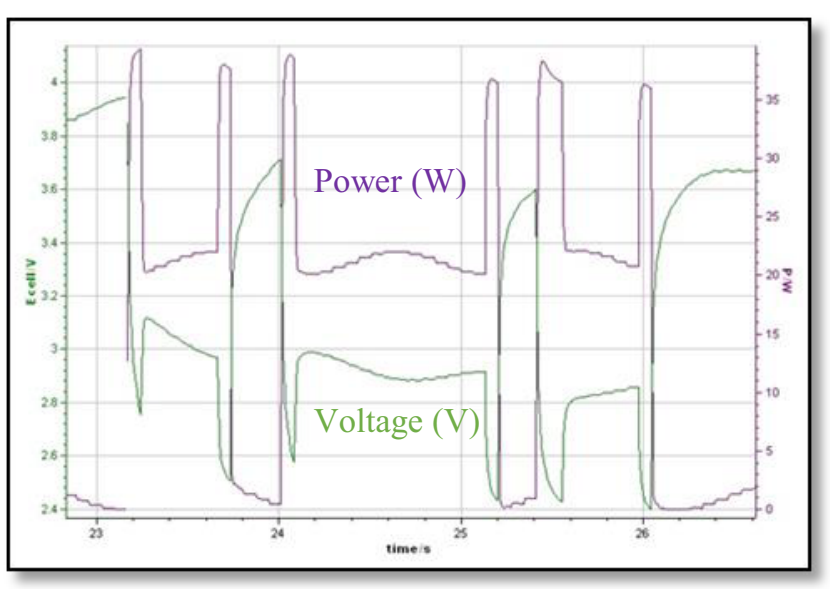

Figure 5. Detail of HPS boost mission at $-20^{\circ} \mathrm{C}(40 \mathrm{~W}$ pulses) for TVC launchers application

Calendar aging results showed very good promise with less than $20 \%$ self-discharge after a year at $45^{\circ} \mathrm{C}$. After 6 months at room temperature self-discharge is less than $3 \%$ (Fig. 6) which can be extrapolated to less than $6 \%$ self-discharge after the target 15 months of storage before being used.

18650 secondary cells were also tested on a FPS mission (preliminary devoted to primary cells) at $-20^{\circ} \mathrm{C}$ and passed the profile, which is very encouraging for minimizing the number of different storage systems in the launcher (one cell technology for all applications).

The final specifications of 18650 secondary cells are presented in Tab 3. A high power of $950 \mathrm{~W} / \mathrm{kg}$ even at $20^{\circ} \mathrm{C}$ allows the required $40 \mathrm{~W}$ of power needed for TVC to be obtained at all tested temperatures. 


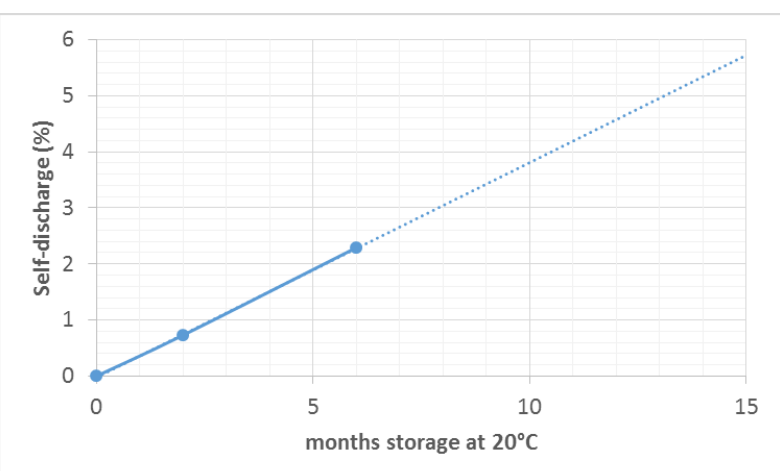

Figure 6: 18650 Self discharge at room temperature

This performance is to be compared to state of the art 18650 cells: for instance the Sony US18650VTC5 [2] considered to be one of the best high power cell on the market. It exhibits a resistance of $150 \mathrm{~m} \Omega$ at $10 \mathrm{~A}$ discharge and $-20^{\circ} \mathrm{C}$. In the same conditions, the developed CEA cells have less than $120 \mathrm{~m} \Omega$ resistance (Fig.7).

Table 3. NMC/Si 18650 cell specifications

\begin{tabular}{|c|c|c|}
\hline $18650 \mathrm{NMC} / \mathrm{Si}$ cells spe & ification & -7 \\
\hline Nominal voltage: & $3.4 \mathrm{~V}$ & \\
\hline Nominal capacity: & $2.4 \mathrm{Ah}$ & \\
\hline Energy: & $8.2 \mathrm{Wh}$ & \\
\hline Internal resistance: & $16 \mathrm{mOh}$ & $(1 \mathrm{kHz})$ \\
\hline & $31 \mathrm{mOh}$ & (5s $100 \%$ SoC) \\
\hline Max continuous current: & $12.5 \mathrm{~A}$ & \\
\hline Energy density: & $200 \mathrm{Wh} /$ & $(\mathrm{C} / 3)$ \\
\hline & $180 \mathrm{Wh} /$ & $(5 C)$ \\
\hline Power density: & $\begin{array}{l}950 \mathrm{~W} / \mathrm{k} \\
(40 \mathrm{~W}, 9 \mathrm{c}\end{array}$ & $\begin{array}{l}\text { from }-20 \text { to }+70^{\circ} \mathrm{C} \\
\mathrm{SoC} \text { ) }\end{array}$ \\
\hline
\end{tabular}

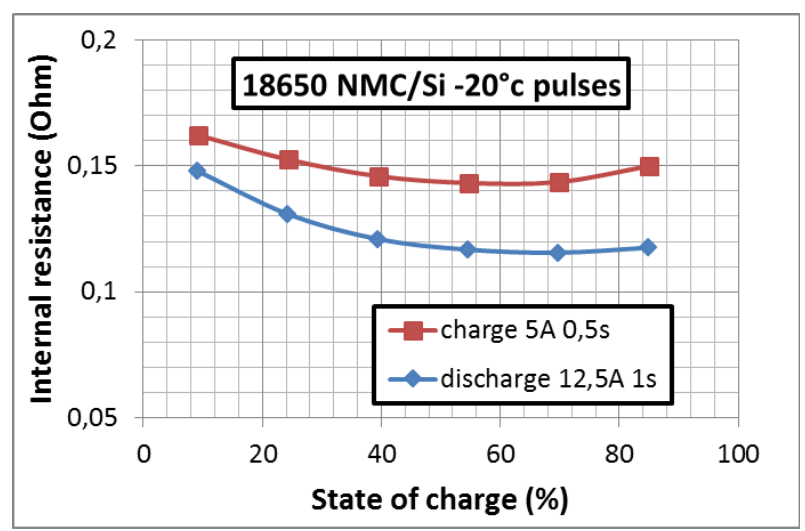

Figure 7. Pulse power capability at $-20^{\circ} \mathrm{C}(\mathrm{NMC} / \mathrm{Si})$

\subsection{Lithium primary cells}

LASER welded AA cells demonstrated exceptionally high energy density $(295 \mathrm{Wh} / \mathrm{kg})$ at the very high rate of $800 \mathrm{~mA}$ (ca. 0.4C) for a primary battery (Fig 8). This rate was chosen because it is the average rate of the FPS mission. Cells passed launchers FPS mission profiles at $+20^{\circ} \mathrm{C}$ and $-20^{\circ} \mathrm{C}$ (Fig 9), as well as vibration testing, as shown in Tab. 4.

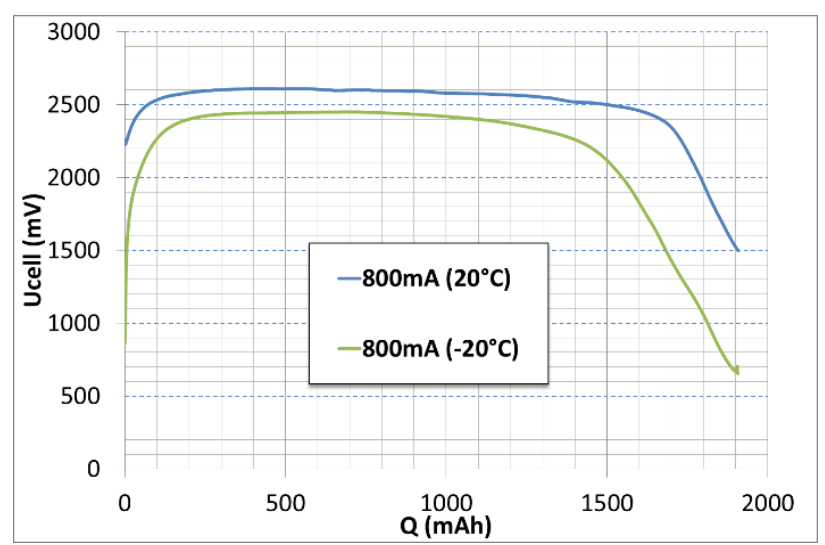

Figure 8. AA $\mathrm{CF}_{\mathrm{x}}$ cells discharge at $800 \mathrm{~mA}(\mathrm{C} / 2.5)$

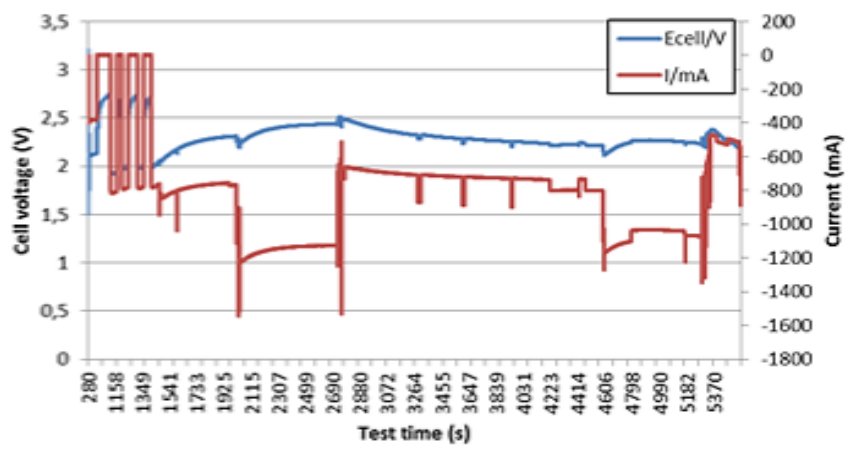

Figure 9. FPS GTO DDO (geostationary transfer orbit, direct deorbitation) profile at $-20^{\circ} \mathrm{C}$ after vibration test

Table 4 : AA CFx cells test plan summary

\begin{tabular}{|l|c|}
\hline \multicolumn{3}{|c|}{ AA: CFx-Li } \\
\hline Sequence Functional Power Supply (FPS) & Status \\
\hline $\begin{array}{l}\text { Reference test :Total capacity and internal } \\
\text { resistance measurement at room temperature }\end{array}$ & Passed $\sqrt{ }$ \\
\hline Mission cycling: FPS GTO DDO at $\mathbf{- 2 0 ^ { \circ } \mathrm { C }}$ & Passed $\sqrt{ }$ \\
\hline Mission cycling: FPS GTO DDO at $\mathbf{2 0 ^ { \circ } \mathrm { C }}$ & Passed $\sqrt{ }$ \\
\hline Calendar test: $\quad 3$ months at $20^{\circ} \mathrm{C}$ & Passed $\sqrt{ }$ \\
\hline Mechanical tests : & Passed $\sqrt{ }$ \\
$-\quad \begin{array}{l}\text { Critical frequency search test \#1 } \\
\text { Vibration : Sine + Random } \\
\text { Critical frequency search test \#2 }\end{array}$ \\
\hline
\end{tabular}

Calendar ageing results after 2 months showed no measurable capacity loss.

It must be noted that several cells showed abnormal behaviour with noisy voltage which was attributed to the low reproducibility of manual assembly with metallic lithium. However thanks to the 3 cells par test used, there was always at least one cell operating as expected to evaluate performance. 
Final specifications of AA primary $\mathrm{CF}_{\mathrm{x}}$ cells are shown in Tab 5: $260 \mathrm{~W} / \mathrm{kg}$ is achieved at $-20^{\circ} \mathrm{C}$ and a constant current of $1.6 \mathrm{~A}$. This discharge rate is especially high for the $\mathrm{CF}_{\mathrm{x}}$ technology known for its usually poor power performance $[3,4]$.

Table 5. $\mathrm{CF}_{\mathrm{X}} / \mathrm{Li}$ AA cell specifications

\begin{tabular}{|ll|}
\hline \multicolumn{2}{|l|}{$\mathbf{A A} \mathbf{C F}_{\mathbf{x}}$ /Li cells specifications } \\
Nominal voltage: & $2.5 \mathrm{~V}$ \\
Nominal capacity: & $1.9 \mathrm{Ah}$ \\
Energy: & $4,75 \mathrm{Wh}$ \\
& \\
Internal resistance: & $130 \mathrm{mOhm}(1 \mathrm{~s})$ \\
Max continuous current: & $0.8 \mathrm{~A}$ \\
Max pulse current: & $1.6 \mathrm{~A}$ \\
Energy density: & $\mathbf{2 9 5} \mathrm{Wh} / \mathrm{kg}(0.8 \mathrm{~A}, \mathrm{RT})$ \\
& $220 \mathrm{Wh} / \mathrm{kg}\left(0.8 \mathrm{~A},-20^{\circ} \mathrm{C}\right)$ \\
& $300 \mathrm{Wh} / \mathrm{kg}\left(1.6 \mathrm{~A},-20^{\circ} \mathrm{C}\right)$ \\
Power density & $\mathbf{2 6 0} \mathrm{W} / \mathrm{kg}(1,6 \mathrm{~A})$ \\
\hline
\end{tabular}

\section{CELLS COMPLIANCE EVALUATION}

The cell level requirements for the different mission profiles are summarized in Tab 6 . They were calculated with a 1.4 cell to battery integration factor and derived from the mission specifications and Airbus DS targets regarding modules weight.

18650 cells measurements (as confirmed by mission profile testing) show it is compliant regarding both energy and power density for the TVC missions. It is close to FPS GTO DDO compliance although it might be slightly too low energy taking into account selfdischarge before mission. Also the voltage profile of the technology being not flat enough it is not compliant versus Airbus DS target voltage range.

Table 6 : Cell level requirements for the different

\begin{tabular}{|l|c|c|}
\hline & $\begin{array}{c}\text { Energy density } \\
(\mathbf{W h} / \mathrm{kg})\end{array}$ & $\begin{array}{c}\text { Power density } \\
(\mathrm{W} / \mathrm{kg})\end{array}$ \\
\hline FPS GTO DDO & 200 & 260 \\
\hline FPS GTO PD & 273 & 80 \\
\hline TVC 1 boost mission & 16 & 700 \\
\hline TVC 2 boost mission & 14.5 & 560 \\
\hline
\end{tabular}

AA 14500 cells were designed to fulfil both FPS GTO DDO and the longer GTO perihelia decrease (PD) missions, taking into account the maximum power and energy density requirement of both profiles. It passed GTO DDO mission confirming the compliance with the specification, but should also be tested against GTO PD mission.

\section{SYSTEM LEVEL TRADE OFF}

Following the test plan results, Airbus DS evaluated both technologies at system level. Final compliance matrix is presented in Tab 7. The NMC/Si was considered as fully compliant for high power supply one or two boosts missions to operate TVC. Primary $\mathrm{CF}_{\mathrm{x}}$ cells were deemed partially compliant for FPS mission due to low voltage reached at $-20^{\circ} \mathrm{C}(-15 \%$ vs. target at system level) at the beginning of the profile. However proper conditioning should solve this issue. Indeed preliminary test showed that initial current pulses just prior to mission can heat up the cell to avoid the voltage drop.

Table 7 : Compliance matrix for the different configurations

\begin{tabular}{|c|c|c|c|c|c|}
\hline Cell type & Mission & $\begin{array}{l}\text { Cell assembly } \\
\text { (module) }\end{array}$ & $\begin{array}{c}\text { Modules } \\
\text { total } \\
\text { mass }\end{array}$ & Target & Comments \\
\hline $\begin{array}{l}14500 \\
\text { CFx-Li }\end{array}$ & $\begin{array}{l}\text { GTO DDO } \\
\text { (FPS) }\end{array}$ & $22 s 13 p$ & $6,4 \mathrm{~kg}$ & $<7 \mathrm{~kg}$ & $\begin{array}{l}\text { Compliant but not } \\
\text { at performance } \\
\text { level (cold temp) }\end{array}$ \\
\hline $\begin{array}{l}14500 \\
\text { CFx-Li }\end{array}$ & $\begin{array}{l}\text { GTO PD } \\
\text { (FPS) }\end{array}$ & $22 s 13 p \times 4$ & $25,6 \mathrm{~kg}$ & $<28 \mathrm{~kg}$ & $\begin{array}{c}\text { Compliant (TBC @ } \\
\text { cold temp) }\end{array}$ \\
\hline $\begin{array}{c}18650 \\
\text { NMC-Si }\end{array}$ & $\begin{array}{l}\text { GTO DDO } \\
\text { (FPS) }\end{array}$ & $15 s 23 p$ & $20,3 \mathrm{~kg}$ & $<7 \mathrm{~kg}$ & uncompliant \\
\hline $\begin{array}{c}18650 \\
\text { NMC-Si }\end{array}$ & $\begin{array}{l}1 \text { boost } \\
\text { (TVC) }\end{array}$ & $41 s 7 p$ & $16,9 \mathrm{~kg}$ & $<20 \mathrm{~kg}$ & compliant \\
\hline $\begin{array}{c}18650 \\
\text { NMC-Si }\end{array}$ & $\begin{array}{l}2 \text { boost } \\
\text { (TVC) }\end{array}$ & $41 s 7 p$ & $16,9 \mathrm{~kg}$ & $<25 \mathrm{~kg}$ & compliant \\
\hline
\end{tabular}

As expected, 18650 cells did not comply with the FPS GTO DDO mission although the energy and power density requirement were met. Indeed the very small voltage window of this application $([53 \mathrm{~V}-63 \mathrm{~V}])$ lead to largely oversizing the module which became too heavy.

Airbus DS evaluated the final technology readiness level (TRL) of primary cells at 4 and secondary cells at 5.

\section{FURTHER ACTIVITIES}

Despite several unexpected issues during cells development on both primary and secondary technologies, the final deliverable passed all the planned tests. 18650 secondary cells even passed the High energy FPS GTO/GTO+ profile, proving it can be used at least for two applications.

A total of 9918650 and 58 AA cells were assembled during the project.

Considering the success of the first test plan, several activities could be pursued:

First, the already good performance of the secondary $\mathrm{NMC} / \mathrm{Si}$ and primary $\mathrm{CF}_{\mathrm{x}}$ technologies could be further improved by working on materials and processing.

The chemistries could also be put into optimized cell formats qualified for space application, for instance Dsize cells with more capacity to minimize the number of cells in parallel in modules and increase the energy 
density.

Mission profile testing also showed that thermal management is critical to evaluate performance. Small modules could be assembled to be representative of the true thermal environments of the cells during launch. Then the cell technologies could be qualified for application on future launchers like Ariane 6.

Finally system management may be adapted to the short length of the target mission in order to save weight on the module

\section{ACKNOWLEDGEMENTS}

This work was conducted under Programme of and funded by the European Space Agency.

\section{esa}

\section{REFERENCES}

1. S. D. Beattie D. Larcher M. Morcrette B. Simon and J.-M. Tarascon, Si Electrodes for Li-Ion Batteries-A New Way to Look at an Old Problem, J. Electrochem. Soc., 1552 A158 (2008)

2. Sony US18650VTC5 cell datasheet https://www.powerstream.com/p/us18650vtc5vtc5.pdf

3. Ganesan Nagasubramanian, Fabrication and Testing Capabilities for $18650 \mathrm{Li} /(\mathrm{CFx}) \mathrm{n}$ Cells, Int. J. Electrochem. Sci., 2913 - 922 (2007)

4. Brochard, P.; Godillot, G.; Peres, J.P.; Corbin, J.; Espinosa, A., Very high specific energy, medium power Li/CFx primary battery for launchers and space probes 10th European Space Power Conference. Proceedings, 59 (2014) 